\title{
Granulometric properties of particles in Upper Miocene sandstones from thin sections, Szolnok Formation, Hungary
}

\author{
Csilla KIRÁlY ${ }^{1}$, György FALUS ${ }^{2,3}$, Fruzsina GRESINA ${ }^{3}$, Gergely JAKAB ${ }^{1,3,4}$, \\ ZoLtÁn SZALAI ${ }^{1,3}$ and GYörgy VARGA ${ }^{1}$
}

\begin{abstract}
Particle size and shape are among the most important properties of sedimentary deposits. Objective and robust determination of granulometric features of sediments is a challenging problem, and has been standingin the focal point of sedimentary studies for many decades. In this study, we provide an overview of a new analytical approach to characterize particles from thin sections of sandstones by using 2D automated optical static image analysis. The analysed samples are originated from the turbiditic Lower Pannonian (Upper Miocene) sediments of Szolnok Formation. Sandstone samples were analysed from 1,500 to 2,250 m depth range. According to the previous studies: the detrital components are quartz, muscovite, dolomite, K-feldspar and plagioclase. Diagenetic minerals are mostly carbonates (calcite, Fe-dolomite, ankerite, siderite), clay minerals (illite, kaolinite), ankerite, siderite and kaolinite. As the discussed Szolnok Formation is considered as a potential $\mathrm{CO}_{2}$ storage system (to reduce atmospheric $\mathrm{CO}_{2}$ concentration), special attention has to be paid on grain size and shape alteration evaluation, since pore water-rock interactions affected by $\mathrm{CO}_{2}$ injection may cause changes in particle properties. The primarily aim of the present study was to develop a method for effective characterization of the particle size and shape of sandstones from thin sections. We have applied a Malvern Morphologi G3SE-ID automated optical static image analyser device, what is completed with a Raman spectrometer. Via the combined analysis of granulometry and chemical characterization, it was obvious that there were specific relationships among various grain shape parameters (e.g., circularity values correlate to width and length ratios, as well as to convexity) and the results indicated that based simply on particle shapes, muscovites can be effectively separated from other minerals. Quartz and feldspar grains showed the highest variability in shapes as these are detrital ones, and sometimes arrived as lithic fragments from which other parts were dissolved The size and shape of carbonate minerals depends highly on the original pore size and shape because these minerals are mainly diagenetic. The shape of detrital dolomites depends on diagenetic ankerite, as it replaces the rim of dolomites.
\end{abstract}

Keywords: grain size; grain shape; sandstone; image analysis; pore water-rock interaction

\section{Introduction}

Particle size and shape analysis of sediments is a basic and widely applied analytical method. Granulometric properties are among the most important features of clastic deposits, containing general information on source areas, transport processes, depositional environment and post-depositional alterations. The different grain size fractions, their abundance and relative proportion provide the basis for the classification of sediments (e.g., sand, aleurite/silt, clay). The physical properties of sediments largely depend on the mass or volumetric proportion of different grain size fractions (WENTwORT, C.K. 1922; FolK, L.R. 1954). Several analytical techniques (e.g., pipette-sieve methods, laser diffraction, static and dynamic image analysis) have been used and applied successfully for particle sizing of unconsolidated,

\footnotetext{
${ }^{1}$ Geographical Institute, Research Centre for Astronomy and Earth Sciences. H-1112 Budapest, Budaörsi út 45. Corresponding author's e-mail: kiraly.csilla@csfk.mta.hu

${ }^{2}$ Mining and Geological Survey of Hungary. H-1145 Budapest, Columbus u. 17-23.

${ }^{3}$ Institute of Geography and Earth Sciences, Faculty of Science, Eötvös University. H-1117 Budapest, Pázmány Péter sétány $1 / \mathrm{c}$.

${ }^{4}$ Institute of Geography and Geoinformatics, University of Miskolc. H-3515 Miskolc, Egyetemváros.
} 
loose sedimentary units (e.g., Quaternary loess, paleosols, windblown or fluvial sands).

Objective and quantitative particle size and shape characterization of consolidated sediments (e.g., sandstones) is a complex issue, generally, several compromises have to be taken during particle size and shape analyses as mineral particles and/or lithic fragments of the deposits has to be analysed mostly in thin sections or on disaggregated sediments (Kellerhals, R. et al. 1975; Burger, H. and Skala, W. 1976; Barrett, P.J. 1980; SсhёFER, A. and Teyssen, T. 1987; Mingireanov Filho, I. et al. 2013; Asmussen, P. et al. 2015; JIANG, F. et al. 2018). Particles in thin sections cannot be regarded as intact grains, cross-sections of sliced non-spherical particles are often not representative for the whole sample, hence, a large number of particles has to be characterized. Disaggregation of the sediments can cause changes in general grain morphology. The morphology of sedimentary particles depends largely on the mineralogy and transport processes, furthermore, the diagenetic processes may also influence the particle shapes as minerals dissolve and re-precipitate, or form during the diagenetic processes (Peтtiтjohn, F.J. 1952). These processes depend on the detrital material, the water chemistry and physical properties (such as porosity, permeability, pressure and temperature) (LARsen, G. and CHILINGAR, G.V. 1979)

In this study, samples from Lower Pannonian (Upper Miocene) Szolnok Formation were investigated from Zagyvarékas. The units comprise fine and very fine sandstones, siltstones, clay marls and marls, with the dominance of sandstones, and are generally regarded as turbidite clastic deposits. The mineral composition of the sedimentary rocks is known, and easy to analyse by X-ray powder diffraction (XRD) or optical microscopy. The main minerals in the sandstone samples from the Lower Pannonian formations are quartz, feldspars, carbonates, clay minerals (MÁTYÁs, J. and Matter, A. 1997; Juhász, A. et al. 2002). These minerals are Raman active, hence mineral compositions can also be determined by Raman spectrometry (Nasdala, L. et al. 2004). After the final deposition of sand grains, burial and associated diagenesis processes have altered the sedimentary deposits. Under these conditions, the deposited detrital grains of sand have gradually been experienced higher pressure and temperature, while the pore water is not in equilibrium with the detrital minerals, hence, some minerals dissolve (e.g., feldspar) whereas others, mainly carbonates and clay minerals, precipitate. The interaction between pore water and grains may cause changes in granulometric parameters of mineral particles and lithic fragments. Furthermore, this is the most potential formation for the $\mathrm{CO}_{2}$ geological storage (Szamosfalvi, Á. et al. 2011). Storage of $\mathrm{CO}_{2}$ in geological formations is a possible method to reduce the atmospheric content of this greenhouse gas, and beside tillage management and appropriate usage of soils (BILANDŽIJA, D. et al. 2017; ZACHÁRY, D. et al. 2018; ZACHÁRY, D. 2019), geological sequestration provides a unique possibility to mitigate the carbon emission. Effects of $\mathrm{CO}_{2}$ on the reservoir pore water-rock system must be well understood before industrial storage projects (BACHU, S. et al. 2007; ArTs, R. et al. 2008; KiráLy, Cs. et al. 2016) are initiated.

The main objective of the study is to present a method, which can help to determine the shape parameter of constituent grains of consolidated sandstones of Szolnok Formation from thin sections. The applied device in this study is a Malvern Morphologi G3SE-ID, a 2D automated optical static image analyser equipped with Raman spectrometer, which enables the determination of morphological properties of grains as well as their mineralogy. Additionally, the whole analytical procedure was carried out in thin sections without the necessity of disintegration of samples and loose textural information.

\section{Geological background and analysed samples}

Zagyvarékas is located in the centre of the Pannonian Basin. Intensive sedimentation characterized this area around 6-7 Ma (MagYar, I. et al. 2013). Series of the sediments started 
with an abyssal deposit (Endröd Formation). The overlying sedimentary facies is a turbiditic sandstone (Szolnok Formation), above the clayey-aleurolite Algyő Formation deposited. These are the Lower Pannonian sediments. The Upper Pannonian sediments consist of a sandy unit (Újfalu Formation) and a strongly varying sequence with alternating sand and clay (Zagyva Formation) (Juhész, Gr. 1992; Juhász, Gy and Thamó-Bozsó, E. 2006). Turbidity deposits characterizing the Szolnok Formation were deposited in a pro-delta subenvironment (Figure 1).
Two sandstone samples (Za1-10/2R and Za1-11/2R) from the vicinity of Zagyvarékas were studied in this paper. The samples originated from the Szolnok Formation, which in some cases deposited in remarkable $>1,000 \mathrm{~m}$ thickness in this area (JuHÁsz, Gr. 1992). The samples were studied in the perspective of $\mathrm{CO}_{2}$ geological storage (Sendula, E. 2015). Grain size distribution, modal composition and petrography were studied in detail also by Sendula, E. (2015). The two analysed samples are light grey, fine-grained sandstones from
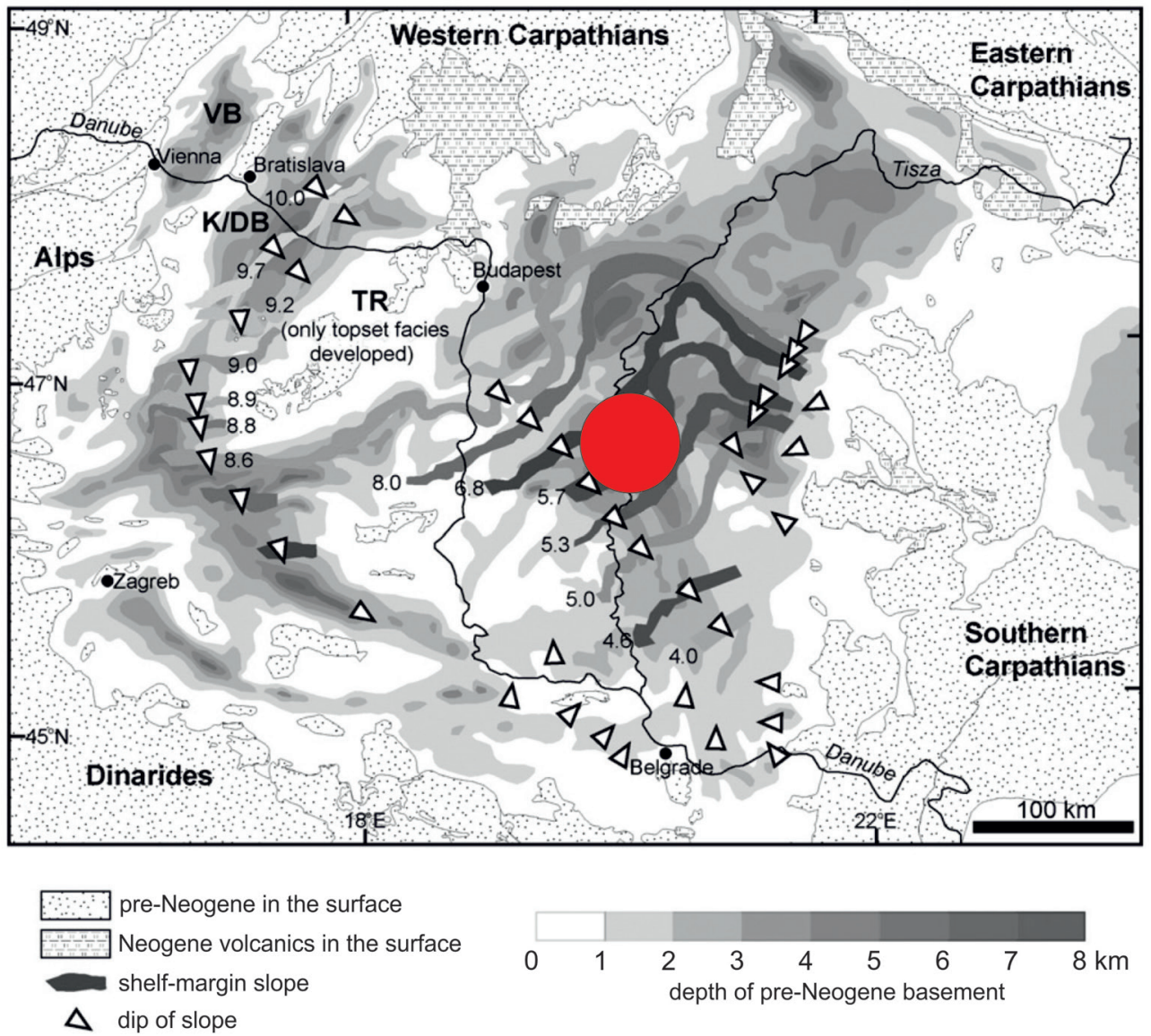

Fig. 1. Progradation of shelf-margin slopes across the Pannonian Basin during Late Miocene and Early Pliocene times. Ribbons $=$ width of the slope; numbers $=$ approximate age in million years; arrows $=$ dip directions as appeared on 2D profiles; $\mathrm{VB}=$ Vienna Basin; $\mathrm{K} / \mathrm{DB}=$ Kisalföld/Danube sub-basin; TR = Transdanubian Range; red circle = study area. Source: Horváth, F. and Royden, L. 1981; Magrar, I. et al. 2013. 
1,867-1,868.5 $\mathrm{m}$ and 2,056-2,061 $\mathrm{m}$ depth. The sandstones are clast-supported, mid-sorted, carbonate cemented materials. According to published laser diffraction analyses, the following grain size fractions are present in the samples: sand $[62.5<\mu \mathrm{m}](59-60 \mathrm{v} / \mathrm{v} \%)$, silt $[2.0-62.5 \mu \mathrm{m}](40-41 \mathrm{v} / \mathrm{v} \%)$ and clay $[<2$ $\mu \mathrm{m}](0.1-0.6 \mathrm{v} / \mathrm{v} \%)$. The grain size distribution curves show two modal peaks $(13.2 \mu \mathrm{m}$ and $152.5 \mu \mathrm{m})$ (Sendula, E. 2015).

The main minerals are quartz, dolomite + ankerite + siderite, illite + muscovite, calcite, plagioclase, kaolinite (Table 1). The petrographic analysis determined that detrital minerals are quartz (as metamorphic rock fragments, mono- and polycrystalline quartz), muscovite, plagioclase, dolomite as well as in a small proportion of calcite and illite is also detrital in origin. Microscopic observations showed that the detrital quartz grains are sub-rounded. According to the 300 points QFL classification, the samples are lithic arenites (Sendula, E. 2015).

Muscovite flakes are oriented parallel to the layering, and as an effect of compaction, some of them were bent and broken (Figure 2). Furthermore, in the sample originating from a greater depth, the ratio of the line contact between grains is increased, indicating stronger compaction (ALI, S.A. et al. 2010; Sendula, E. 2015).

Diagenetic minerals are carbonate minerals, clay minerals, quartz overgrowth and plagioclase (just in Za1-11/2R). The cement material is a mixture of ankerite, calcite, siderite and kaolinite. The main part of ankerite occurs as mineral replacement of dolomite, followed by ankerite overgrowth. The siderite is a finegrained pore-filling material, which may be formed from biotite. Kaolinite is also present between muscovite layers (SEndula, E. 2015).

The petrography of the sandstones indicates that during the diagenetic processes albite formed from plagioclase. Subsequently, one part of albite dissolved and kaolinite replaced the albite. In the $\mathrm{Za1}-11 / 2 \mathrm{R}$ sample, authigenic plagioclase is also present. The porosity of the samples is $8-10$ per cent (Sendula, E. 2015).

\section{The methodology of 2D image analysis}

Recently, morphological characterization of grains is also a dynamically developing method when studying various sediments (Moss, A.J. 1996; Rogers, C.D.F and SMALLEY, I.J. 1993; VARGA, Gy. et al. 2018; VARGA, Gy. and Roettig, C.-B. 2018). Originally the morphological characterization of particles was not a mathematically grounded method, however, recently the 2D automated optical static image analysis enabled the solution of this problem. Furthermore, earlier the number of analysed grains was not sufficient for robust statistical analysis, this problem has also been successfully overcome with automatized systems (Cox, M.R. and BudHu, M. 2008). Using well established mathematical toolset and considering more shape properties it seems clear that the widely used Krumbein-classification does not work (SocHAN, A. et al. 2015). Earlier studies based on this methodology have to be revised.

Thin sections of the two sandstone samples in blue-coloured epoxy resin were measured by Malvern Morphologi G3 SE-ID instrument in the Laboratory for Sediment

Table 1. Modal composition, porosity and grain fractions of the studied samples

\begin{tabular}{|c|c|c|c|c|c|c|c|c|c|c|}
\hline \multirow{3}{*}{ Samples } & \multirow[b]{2}{*}{ Quartz } & \multirow{2}{*}{$\begin{array}{l}\text { Dolomite } \\
+ \text { ankerite } \\
+ \text { siderite }\end{array}$} & \multirow{2}{*}{$\begin{array}{c}\text { Illite }+ \\
\text { muscovite }\end{array}$} & \multirow[b]{2}{*}{ Calcite } & \multirow[b]{2}{*}{ Plagioclase } & \multirow[b]{2}{*}{ Kaolinite } & \multirow[b]{2}{*}{ Porosity } & Sand & Silt & Clay \\
\hline & & & & & & & & \multicolumn{3}{|c|}{ fractions } \\
\hline & \multicolumn{7}{|c|}{$\mathrm{m} / \mathrm{m} \%$} & \multicolumn{3}{|c|}{$\mathrm{v} / \mathrm{v} \%$} \\
\hline Za1-10/2R & 49 & 21 & 11 & 9 & 4 & 6 & 10.33 & 58.84 & 40.50 & 0.62 \\
\hline Za1-11/2R & 50 & 14 & 15 & 10 & 7 & 4 & 8.33 & 60.03 & 39.80 & 0.15 \\
\hline
\end{tabular}

Source: Sendula, E. 2015. 

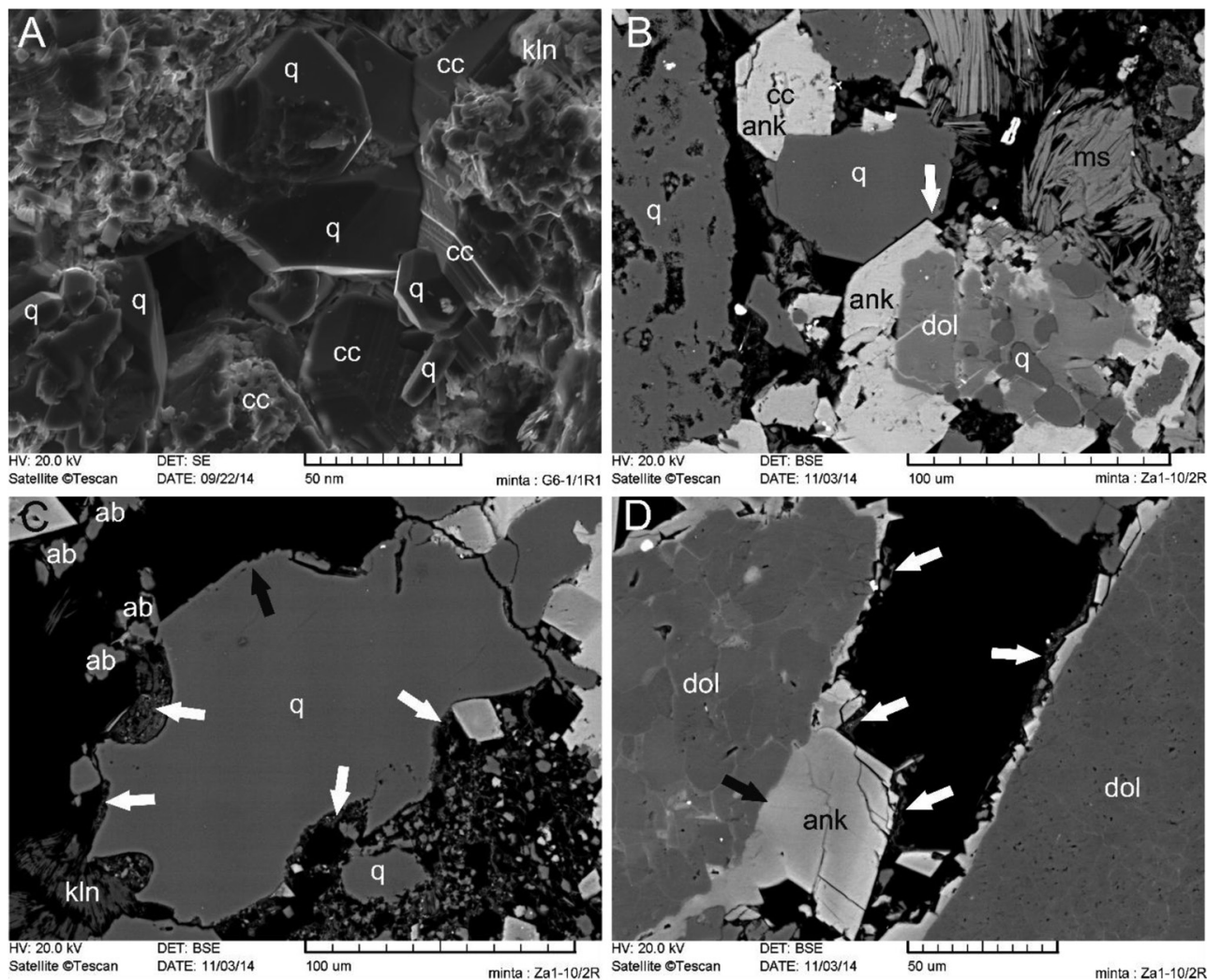

Fig. 2. Scanning electron images from Za1-10/2R and Za1-11/2R samples. A = a secondary electron image, where quartz overgrowth can be observed with diagenetic calcite. $\mathrm{B}=$ a backscattered electron image where ankerite cement precipitated around dolomite, the morphology of ankerite depends on the quartz (arrow). The muscovite crystals are broken in this sample. $\mathrm{C}=\mathrm{a}$ backscattered electron image showing that albite dissolved from albite-quartz rock fragment, furthermore kaolinite precipitated from albite. $\mathrm{D}=$ also a backscattered electron image, where different morphological properties of dolomite-ankerite assemblage can be observed, which show dependence on a thin clay layer around the carbonates (SEndula, E. 2015).

and Soil Analysis (Geographical Institute, Research Centre for Astronomy and Earth Sciences). Contrary to widely used laser diffraction measurements, image analysis provides direct observational data of particle size, and due to the automatic measurement technique, a large number of particles are characterized allowing us a more robust and objective granulometric description of particles compared to manual microscopic approaches (VARGA, Gy. et al. 2018).

$55 \mathrm{~mm}^{2}$ areas of the thin sections were scanned by using the $2.5 \times$ and $5 \times$ objective lenses of the built-in Nikon eclipse microscope and CCD camera, providing 1.2 and 0.3 $\mu^{2} /$ pixel resolution, respectively (Figure 3). The focus was manually determined, and we did not use $Z$ stacking (no additional vertical focal planes were used). The applied greyscale intensity threshold was 0-45 in case of $2.5 \times$ objective, and $0-57$ in case of $5 \times$ objective. All of the scanned grains are stored as separate greyscale images and several size and shape parameters are determined automatically (Table 2). After the measurement, the program saves a high-resolution image from 

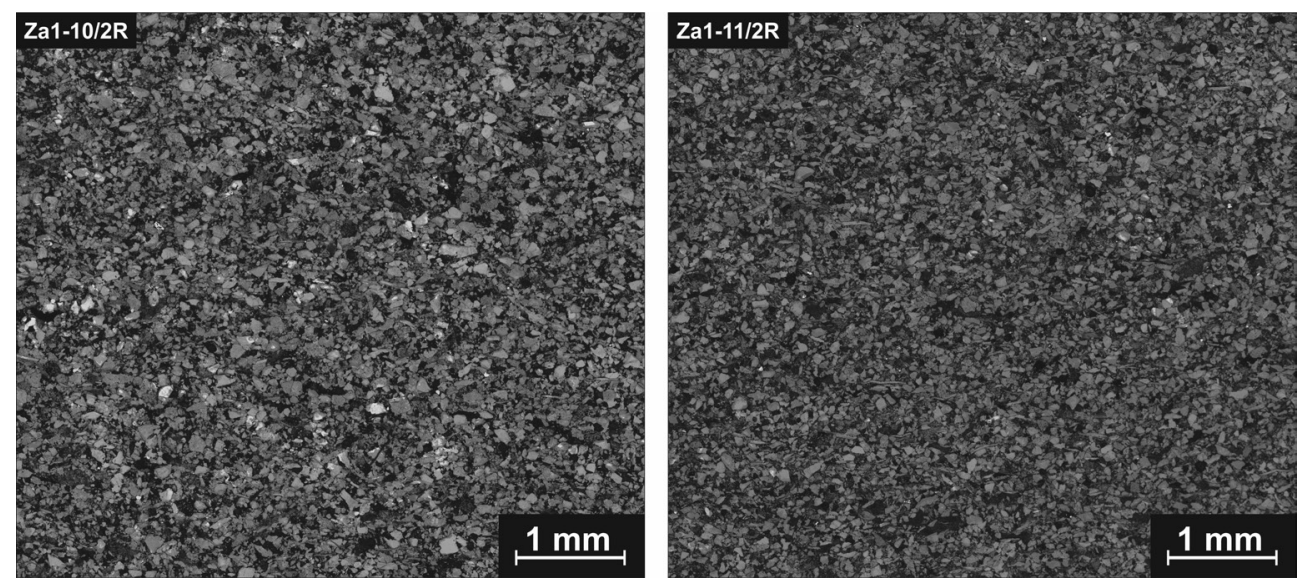

Fig. 3. Scanned thin section images

Table 2. Mathematical background of the different morphological parameters

\begin{tabular}{|c|c|c|}
\hline Parameter & Equation & Description \\
\hline Area (pixel) & & $\begin{array}{l}\text { Particle area in pixels (pixel size } \\
\text { is dependent on resolution) }\end{array}$ \\
\hline Area $\left(\mu \mathrm{m}^{2}\right)[\mathrm{A}]$ & & Particle area in $\mu \mathrm{m}^{2}$ \\
\hline Aspect ratio [AR] & $\mathrm{W} / \mathrm{L}$ & Particle width and length ratio \\
\hline Circle equivalent diameter [CED] & $\mathrm{D}=\mathrm{A}$ & $\begin{array}{l}\text { Diameter of a circle with the } \\
\text { same area as the particle }\end{array}$ \\
\hline Centre $X$ position $(\mu \mathrm{m})$ & & Particle location coordinate \\
\hline Centre $\mathrm{Y}$ position $(\mu \mathrm{m})$ & & Particle location coordinate \\
\hline Circularity $[\mathrm{C}]$ & $\left(2 \times \pi^{0.5}-\mathrm{A}^{0.5}\right) / \mathrm{P}=(\mathrm{CED} \times \pi) / \mathrm{P}$ & $\begin{array}{l}\text { Proportional relationship } \\
\text { between the circumference of a } \\
\text { circle equal to the object's pro- } \\
\text { jected area and perimeter }\end{array}$ \\
\hline Convexity [K] & $\begin{array}{c}\mathrm{P}_{\text {conv }} / \mathrm{P} \text {, where } \mathrm{P}_{\text {conv }} \text { is the perimeter } \\
\text { of convex hull }\end{array}$ & $\begin{array}{l}\text { Ratio of perimeter of the convex } \\
\text { hull to the particle perimeter }\end{array}$ \\
\hline Spherical equivalent volume $\left(\mu \mathrm{m}^{3}\right)$ & $(\pi \times \mathrm{CED})^{3} / 6$ & $\begin{array}{l}\text { Volume of a sphere with CED of } \\
\text { the particle }\end{array}$ \\
\hline Width $(\mu \mathrm{m})[\mathrm{W}]$ & & Particle width \\
\hline Elongation [E] & $1-\mathrm{W} / \mathrm{L}=1-\mathrm{AR}$ & 1 minus AR \\
\hline High sensitivity circularity [HS C] & $\mathrm{C}^{2}=\left(\left(2 \times \pi^{0.5}-\mathrm{A}^{0.5}\right) / \mathrm{P}\right)^{2}=((\mathrm{CED} \times \pi) / \mathrm{P})^{2}$ & $\begin{array}{l}\text { Ratio of the object's projected area } \\
\text { to the square of the perimeter of } \\
\text { the object }\end{array}$ \\
\hline Intensity mean [Ia] & $\left(\sum_{1=1}^{i=N} \mathrm{I}_{j}\right) / \mathrm{N}$ & Mean value of particle intensities \\
\hline Intensity standard deviation & $\left(\left(\mathrm{Ia}^{2}-\left(\mathrm{Ia}^{2} / \mathrm{N}\right) / \mathrm{N}\right)^{0.5}\right.$ & $\begin{array}{l}\text { Standard deviation of particle } \\
\text { intensities }\end{array}$ \\
\hline Length $(\mu \mathrm{m})[\mathrm{L}]$ & & Particle length \\
\hline Major axis $\left({ }^{\circ}\right)$ & & $\begin{array}{l}\text { Angle of the Major Axis from a } \\
\text { horizontal line }\end{array}$ \\
\hline Max distance $(\mu \mathrm{m})$ & & $\begin{array}{l}\text { Furthest distance between any } \\
\text { two points of the particle }\end{array}$ \\
\hline Perimeter $(\mu \mathrm{m})[\mathrm{P}]$ & & Particle perimeter \\
\hline Solidity & $\mathrm{A} / \mathrm{P}_{\text {conv }}$ & $\begin{array}{l}\text { Ratio of the particle and convex } \\
\text { hull areas }\end{array}$ \\
\hline
\end{tabular}


the scan area, which can be used for further analyses of the sample.

Circle-equivalent (CE) diameter is regarded as the most important size parameter of image analytical sizing techniques of the nonspherical, irregular-shaped particles. It is calculated as the diameter of a circle with the same area as the projected two-dimensional particle image. To transform number-based distributions into volume-based distributions sphere-equivalent (SE) diameter is used as a weighting factor. The volume of a given size bin is specified by weighting with the total SE volume of particles classed into this size range.

Length and width are estimated from major and minor axes of the particles (Malvern Instruments Ltd. 2015). All perimeter points of the object are projected onto the major axis (minor axis), and the longest distance between the points is the length (width) of the particle as shown in Figure 4. Other simple grain size parameters as particle area or perimeter can easily be determined using the acquired images.

Aspect ratio is the ratio of width and length, while elongation is calculated as 1-aspect ratio. The circularity parameter of a particle describes the proportional relationship between the circumference of a circle equal to the object's projected area and perimeter, while High Sensitivity (HS) circularity is the ratio of the object's projected area to the square of the perimeter of the object. Convexity and solidity are determined using the convex hull (theoretical rubber band wrapped around the particle - indicated as grey area on Figure 4) of the two-dimensional images. Convexity is the ratio of the perimeter of the convex hull to the particle perimeter, while solidity is the ratio of the particle and convex hull areas; these are parameters of the particle edge roughness. Relation between the particle shape parameter were described with correlation analyses and f-test in Microsoft Excel.

Simultaneously, the mean greyscale intensity and standard deviation of particles were also measured from the images. White light intensity of each pixel of particles is recorded on an 8 -bit $\left(2^{8}\right)$ scale from 0 to 255 , where the intensity value of zero is white, 255 is black.

Phase analysis was performed using the built-in Raman spectrometer of the Malvern Morphologi G3 SE-ID. The laser of Raman spectroscope was operating with the following parameters: wavelength: $785 \mathrm{~nm}$, energy: $<500 \mathrm{~mW}$, measurement time: $5 \mathrm{sec}$. Spectra were acquired from several hundreds of targeted individual particles. These spectra were compared with library spectra (BioRadKnowItAll Informatics System 2017, Raman ID Expert) and correlation calculations were performed to determine the mineralogy of the targeted sedimentary grains.

Image analysis-based measurements were organized into a number-based database. All of the particles have their own identity number (ID) being the primary key in the data matrix. Each row represents one particle, while the columns are various size and shape parameters, completed with light transmissivity data and Raman correlation scores. Large numbers of measured particles ensure a statistically robust and objective insight into the granulometric characteristics of the investigated samples.
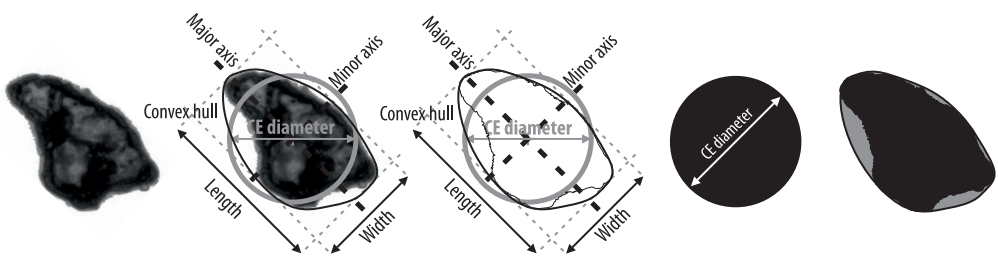

Aspect Ratio: 0.621

CE Diameter: $59.89 \mu \mathrm{m}$

Circularity: 0.667

Convexity: 0.752

Elongation: 0.379

SE Volume: $112467.58 \mathrm{\mu m}^{3}$

Solidity: 0.922

Fig. 4. Schematic illustration of major grain size and shape parameters of irregular mineral particles (grey areas represent the convex hull - modified after VARGA, Gy. et al. 2018) 


\section{Results and discussion}

Grain size results of image analysis based on $n_{\text {Za1-10/2R }}=26,501$ and $n_{\text {Za1-11/2R }}=34,362$ individual particles indicates the high volumetric proportion of fine sand-sized fractions in the samples. Mean $(\mathrm{D}[4,3])$ diameters of the samples are $75.8 \mu \mathrm{m}$ and $76.2 \mu \mathrm{m}$, respectively. The unimodal volumetric grain size distribution curves have their maxima in the fine sand fraction, while the modal values of number-based distributions are located around $3 \mu \mathrm{m}$ (Figure 5). Volumetric size fractional proportions are the followings: Za-1-10/2R: clay: 0.04 per cent; silt: 61.36 per cent; sand: 38.6 per cent; Za-1-11-10/2R: clay: 0.019 per cent; silt: 54.43 per cent; sand: 45.56 per cent.
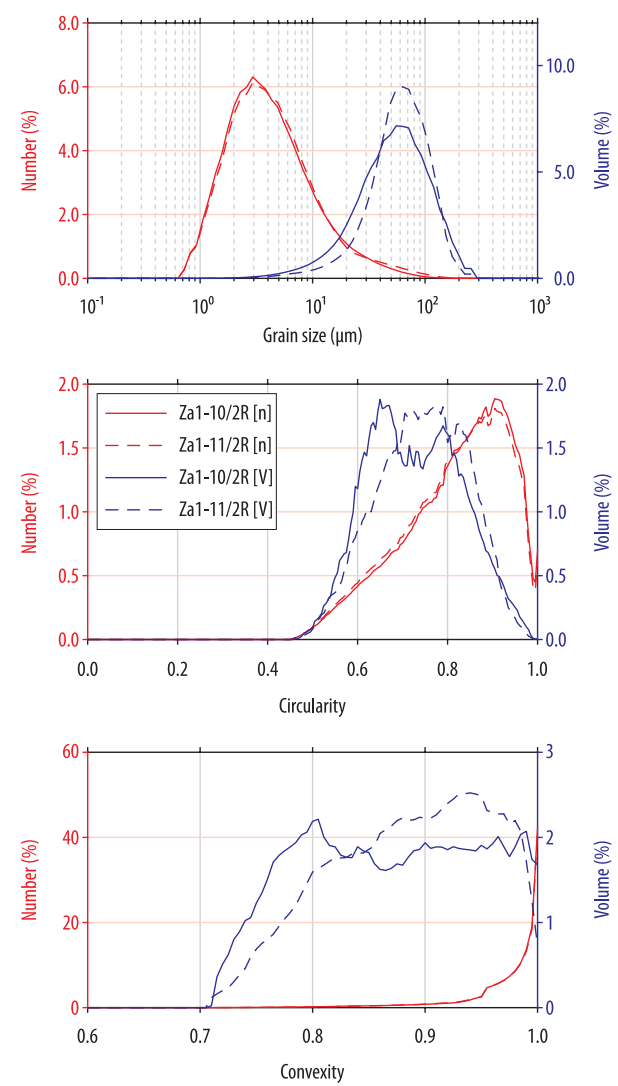

Intensity curves indicate a more homogeneous grayscale patter of Za1-11/2R sample and the presence of some scarce but rather large outlying dark particles in Za1-10/2R sample (also visible in Figure 3). The shape parameters show similarly the higher volumetric proportion of more irregularly shaped particles (lower nominal values of volumetric curves) in Za-1-10/2R sample. It is worth noting, that in all cases, the number-based shape distribution curves incline into the direction of more spherical general shape-character as a result of a high number of very fine particles with quite low-resolution (resulting blurred edges) at the applied magnifications.

Analyses of Raman spectra of selected $n=70$ particles from the coarse silt-fine sand
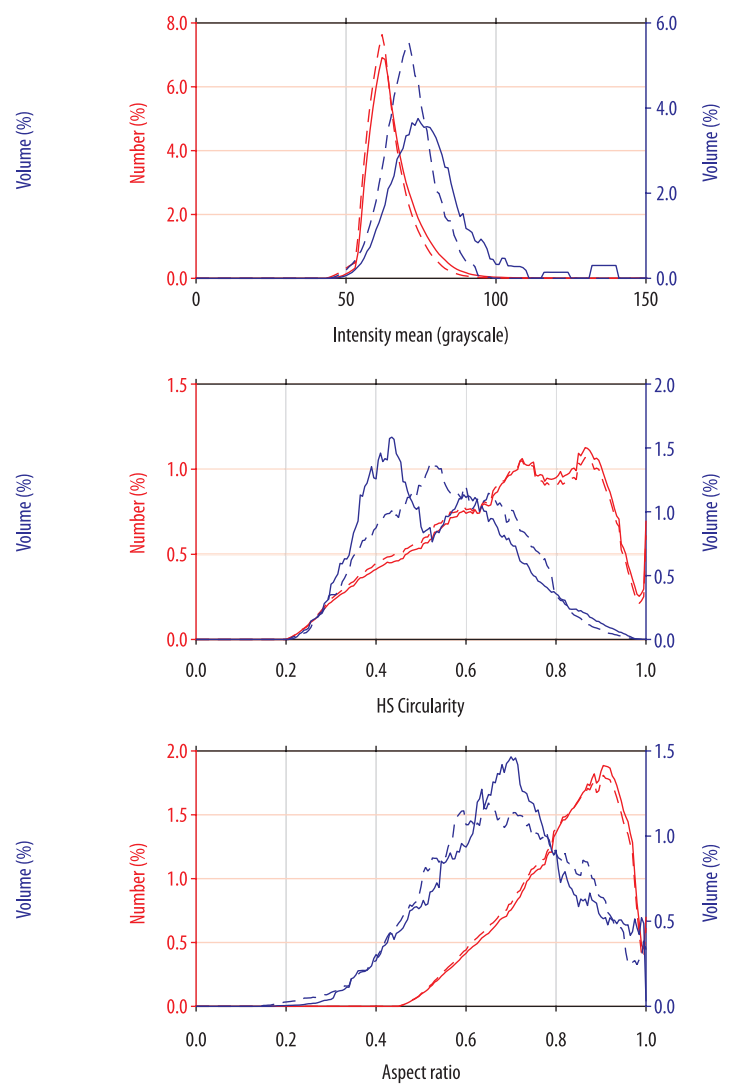

Fig. 5. Number- (n [red]) and volume- (V [blue]) based distribution curves of selected granulometric and optical parameters of bulk samples 
fractions Za1-11/2R show that the main minerals in the studied fractions are quartz $(75 \%)$, feldspar $(11 \%)$, carbonates $(9 \%)$ and mica (3\%). The studied fractions show differences in Za1-10/2R ( $\mathrm{n}=90)$, where the carbonate $(21 \%)$, feldspar $(18 \%)$ and mica $(6 \%)$ is higher and amount of quartz is significantly lower (56\%).

The results of the shape analysis show that the quartz and feldspar particles have the most diverse appearance. Mica morphological parameters show minor variation, while shape parameters of carbonates are more diverse, but not as much as the quartz or feldspars (Table 3).

Volumetric grain size distributions were calculated from the number-based size distributions by weighting with SE diameter (raw number-based size distribution show rather different curves, but this cannot be compared to results of previous volumetric laser diffraction results by Sendula, E. 2015). The volumetric grain size results of image analysis, however, showed a completely different picture from the laser diffraction. This is logical consequence of the different approaches. The indirect estimations of laser devices are always dependent on several unknown factors (e.g., representative complex refractive index of the polymineral sample) beside the composition of the real particles (VARGA, Gr. et al. 2019). Another, explanation of this discrepancy could be that the selected objectives are ideal for detailed characterization of particles larger than $6.5 \mu \mathrm{m}$ in diameter, on the other hand, significant size polydis- persity of the samples (particle sizes ranging from clay to sand fractions) is a known issue of image analysis-based sizing. Very few amount of large particles have a remarkable effect on size distribution curve if the number of scanned particles is not sufficient (depending on the polydispersity, sufficient number could be several tens or hundreds of thousands of particles), indicating the unavoidable necessity of usage of automated approaches. Consequently, the whole range of sample grain size distribution in a relatively small $(1 \times 1)$ thin section cannot be determined without compromises, for instance, large grains $(>200 \mu \mathrm{m})$ are visible with objective $2.5 \times$, the other grains can be analysed by objective $5 \times$, and clay patches may be studied by using the $20 \times$ magnification lens providing a resolution of $0.019 \mu \mathrm{m}^{2} /$ pixel.

The correlation analysis of various shape parameters shows that there is a strong correlation between HS circularity and convexity $(\mathrm{r}=0.75, \mathrm{p}<0.001)$ and between HS circularity and aspect ratio $(\mathrm{r}=0.60, \mathrm{p}<0.001)$ (Figure 6). However, we have to note, that the shape parameters of muscovite depend on the kaolinite between the muscovite layers (Sendula, E. 2015), which led to misinterpretations. Consequently, if muscovite is excluded from the analysis, the correlation becomes stronger.

Determination of roundness (described in detail by Krumbein, W.C. 1941; Krumbein, W.C. and Stoss, L.L. 1951) was carried out on quartz particles. This quite widely used parameter is not defined mathematically

Table 3. Results of shape analyses of selected particles

\begin{tabular}{|c|c|c|c|c|c|}
\hline \multirow{2}{*}{ Sample } & \multirow{2}{*}{ Mineral } & \multirow{2}{*}{ Number } & HS circularity & Aspect ratio & Convexity \\
\hline & & & \multicolumn{3}{|c|}{$\min -\max$} \\
\hline Za1-10/2R & $\begin{array}{l}\text { quartz } \\
\text { feldspar } \\
\text { carbonates } \\
\text { mica }\end{array}$ & $\begin{array}{r}38 \\
12 \\
14 \\
4\end{array}$ & $\begin{array}{l}0.19-0.85 \\
0.31-0.73 \\
0.40-0.75 \\
0.15-0.24\end{array}$ & $\begin{array}{l}0.15-0.97 \\
0.32-0.81 \\
0.34-0.80 \\
0.15-0.36\end{array}$ & $\begin{array}{l}0.81-0.99 \\
0.91-0.98 \\
0.81-0.98 \\
0.81-0.91\end{array}$ \\
\hline Za1-11/2R & $\begin{array}{l}\text { quartz } \\
\text { feldspar } \\
\text { carbonates } \\
\text { mica }\end{array}$ & $\begin{array}{r}86 \\
12 \\
10 \\
6\end{array}$ & $\begin{array}{l}0.19-0.82 \\
0.40-0.91 \\
0.45-0.72 \\
0.10-0.40\end{array}$ & $\begin{array}{l}0.21-0.99 \\
0.43-0.91 \\
0.46-0.81 \\
0.15-0.32\end{array}$ & $\begin{array}{l}0.76-0.99 \\
0.79-1.00 \\
0.84-0.94 \\
0.82-0.93\end{array}$ \\
\hline
\end{tabular}



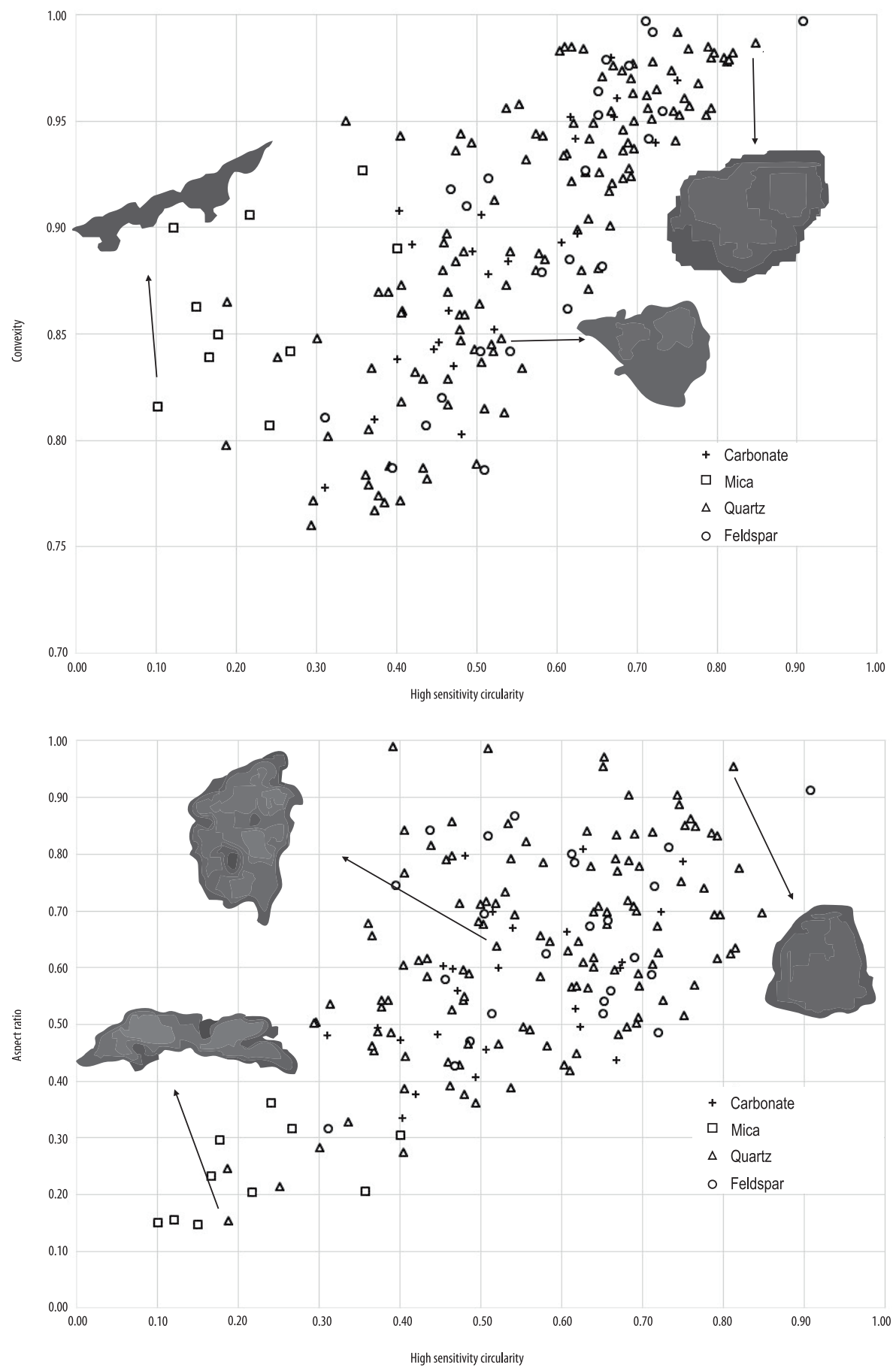

Fig. 6. Particle shape properties are in correlation (HS circularity-convexity, HS circularity-aspect ratio) in case of the two studied samples (Za1-10/2R, Za1-11/1R) 
and is regarded as a semi-quantitative approach (KIM, Y. et al. 2019), it depends on the convexity and HS circularity (XIA, W. 2017). According to SEndula, E. (2015) these samples are sub-rounded, however, the morphological parameters of quartz show that HS circularity (0.19-0.85) and convexity (0.76-0.99) are very diverse. The convexity in natural grains is generally $>0.7$, for this reason, the clumped or aggregated grains were filtered by using proper thresholds of convexity $(0.75$, which was checked according to the deleted grains). For this reason, the classification of roundness cannot be determined based on the results of 2D image analyses. This is in harmony with Sochan, A. et al. (2015), who demonstrated that KrumbeinSloss classification is not working in case of 2D image analysis.

The effect of fluid-rock interaction is expected to influence the morphological properties of certain grains. Consequently, complex interpretation of shape analysis is necessary to understand what reactions could have taken place in the system. Quartz is mainly a detrital mineral which deposited as rock fragments, polycrystalline and monocrystalline quartz. In the rock fragments, different minerals are present (feldspar, mica, carbonate), which may have dissolved during the diagenesis. Furthermore, during the diagenetic processes quartz overgrowth occurred, which also affected the particle shapes. These phenomena contribute to the varying appearance of quartz. The feldspar is also mainly a detrital mineral, which is partly dissolved during the diagenetic processes. The dissolution of feldspar can cause lower convexity and HS circularity values. The carbonates are present both as detrital and diagenetic minerals. According to the petrography, ankerite precipitated around dolomite, which may change the morphological properties of these complex carbonate grains. Part of calcite is detrital, which may easily deform during the compaction. This effect also influenced the shape parameters. Therefore, morphological parameters of carbonates depend largely on the free pore space, and from clay coatings (see also in Figure 2). As a re- sult of sheet-like shape, muscovite is deposited with its flat surface parallel to sedimentary layering. Subsequently, the muscovite is slightly deformed as a result of compaction and kaolinite precipitated between its layers. These effects caused the low convexity and HS circularity values in mica crystals.

The automated identification of minerals of the investigated thin section, the modal composition of samples can be determined precisely in a faster and more exact way compared to the widely used 300-poins analysis. However, due to the inaccurate determination of the proportion of lithic fragments, the Q-F-L classification cannot be done without manual control.

\section{Conclusions}

It was demonstrated that Malvern Morphologi G3 SE-ID system is capable to determine various size and shape parameters and mineral composition of a large number of particles from thin sections of sandstone samples. The results show that the particle shapes of minerals were amended during the diagenetic processes. The most useful parameters to characterize the particle shapes in sandstones are HS circularity, convexity and aspect ratio, which may describe the roundness of the particles. The advantages of the method are the following: (1) high resolution/high-quality image from the scanned area; (2) mineral composition of grain size fractions can be clearly and easily defined; (3) particle shape analysis of particles from thin sections; (4) particle size and shape distributions in selected size-fraction; and (5) the thin section and its high resolution scanned image is available for further analysis.

With further studies, the clarification of how diagenetic processes affect the morphology of particles and pores can be achieved. However, we notice disadvantages of the methods: (1) the important grain size fractions have to be chosen; (2) clay fraction cannot be examined; and (3) QFL diagram can only be done with manual control. 
Acknowledgement: Support of the National Research, Development and Innovation Office NKFIH K131353, K120620, FK-128230 is gratefully acknowledged. The research was additionally supported by KEP-08. Supported by the ÚNKP-19-3 New National Excellence Program of the Ministry for Innovation and Technology.

\section{REFERENCES}

Ali, S.A., Clark, W.J., Moore, W.R. and Dribus, J.R. 2010. Diagenesis and reservoir quality. Oilfield Review Summer 22. (2): 14-27.

Arts, R., Beaubien, S., Benedictus, T., CzernichowskiLauriol, I., Fabriol, H., Gastine, M., Gundogan, O., Kirby, G., Lombardi, S., May, F., Pearce, J., Persoglia, S., Remmelts, G., Riley, N., Sohrabi, M., Stead, R., Vercelli, S. and Vizika-Kavvadias, O. 2008. What does $\mathrm{CO}_{2}$ geological storage really mean? $\mathrm{CO}_{2}$ GeoNet 3-19.

Asmussen, P., Conrad, O., Günther, A., Kirsch, M. and RiLLER, U. 2015. Semi-automatic segmentation of petrographic thin section images using a "seeded-region growing algorithm" with an application to characterize wheathered subarkose sandstone. Computers and Geosciences 83. 89-99.

Bachu, S., Bonijoly, D., Bradshaw, J., Burruss, R., Holloway, S., Christensen, N.P. and Mathiassen, O.M. 2007. $\mathrm{CO}_{2}$ storage capacity estimation: Methodology and gaps. International Journal of Greenhouse Gas Control 1. 430-443.

BARRETT, P.J. 1980. The shape of rock particles, a critical review. Sedimentology 27. 291-303.

BilandžIJA, D., ZgoreleEc, Ž. and Kisić, I. 2017. Influence of tillage systems on short-term soil $\mathrm{CO}_{2}$ emissions. Hungarian Geographical Bulletin 66. (1): 29-35.

Burger, H. and Skala, W. 1976. Comparison of sieve and thin-section technique by a Monte-Carlo model. Computers and Geosciences 2. 123-139.

Cox, M.R. and Budhu, M. 2008. A practical approach to grain shape quantification. Engineering Geology 96. 1-16.

FoLK, L.R. 1954. The distinction between grain size and mineral composition in sedimentary-rock nomenclature. The Journal of Geology 62. 344-359.

Horváth, F. and Royden, L. 1981. Mechanism for formation of the intra-Carpathian basins: a review. Earth Evolution Sciences 1. 307-316.

JiAng, F., Gu, Q., HaO, H., Li, N., Wang, B. and Hu, X. 2018. A method for automatic grain segmentation of multi-angle cross-polarized microscopic images of sandstone. Computers and Geosciences 115. 143-153.

Juhász, A., M. Tóth, T., Ramseyer, K. and Matter, A. 2002. Connected fluid evolution in fractured crystalline basement and overlying sediments, Pannonian Basin, SE Hungary. Chemical Geology 182. 91-120.
JuHÁsz, Gy. 1992. A pannóniai (s.l.) formációk térképezése az Alföldön: elterjedés, fácies és üledékes környezet (Pannonian [s.l.] lithostratigraphic units in the Great Hungarian Plain: distribution, fades and sedimentary environment). Földtani Közlöny 122. 133-165.

Juhász, Gy. and Thamó-Bozsó, E. 2006. Az alföldi pannóniai s.1. képződmények ásványi összetétele II. - A pannóniai s.1. homokok és homokkövek ásványi összetétel változásának tendenciái és földtani jelentőségük (The mineral composition of the Pannonian s.l. Formations in the Great Hungarian Plain II. - Tendencies of the changes of the mineral composition of the Pannonian s.l. sands and sandstones and their geological significance). Földtani Közlöny 136. (2): 431-450.

Kellerhals, R., Shaw, J. and Arora, V.K. 1975. On grain size from thin sections. The Journal of Geology 83. 79-96.

KIM, Y., SUH, H.S. and YUN, T.S. 2019. Reliability and applicability of the Krumbein-Sloss chart for estimating geomechanical properties in sands. Engineering Geology 248. 117-123.

Király, Cs., Sendula, E., Szamosfalvi, Á., Káldos, R., Kónya, P., Kovács, I.J., FüRI, J., Bendő, Zs. and Falus, Gy. 2016. The relevance of dawsonite precipitation in $\mathrm{CO}_{2}$ sequestration in the MihályiRépcelak area, NW Hungary. In Reservoir Quality of Clastic and Carbonate Rocks: Analysis, Modelling and Prediction. Eds.: Armitage, P.J., Butcher, A.R., Churchill, J.M., Csoma, A.E., Hollis, C., LANDER, R.H., OMma, J. and Worden, R.H., Special Publications. London, Geological Society. Available at http://doi.org/10.1144/SP435.15

Krumbein, W.C. 1941. Measurement and geological significance of shape and roundness of sedimentary particles. Journal of Sedimentary Petrology 11. 64-72.

Krumbern, W.C. and Sloss, L.L. 1951. Stratigraphy and Sedimentation. San Francisco, W.H. Freeman and Company.

Larsen, G. and Chilingar, G.V. 1979. Diagenesis in Sediments and Sedimentary Rocks. New York, Elsevier.

Magyar, I., Radivojevic, D., Sztanó, O., Synak, R., Ujszászi, K. and Pócsik, M. 2013. Progradation of the paleo-Danube shelf margin across the Pannonian Basin during the Late Miocene and Early Pliocene. Global and Planetary Change 103. 168-173. Malvern Instruments Ltd. 2015. Morphologi G3 User Manual. Malvern, United Kingdom.

Mátrás, J. and Matter, A. 1997. Diagenetic indicators of meteoric flow in the Pannonian Basin, Southeast Hungary. Basin-wide diagenetic patterns: Integrated petrologic, geochemical, and hydrologic considerations. SEPM Special Publication 57. 281-296.

Mingireanov Filho, I., Valuin Sinina, T., Xavier Falcão, A. and Campane Vidal, A. 2013. Segmentation of sandstone thin section images with separation of 
touching grains using optimum path forest operators. Computers and Geosciences 57. 146-157.

Moss, A.J. 1966. Origin, shaping and significance of quartz sand grains. Journal of the Geological Society of Australia 13. 97-136.

Nasdala L., Smith, D.C., Reinhard, K. and Ziemann, M.A. 2004. Raman spectroscopy: Analytical perspectives in mineralogical research. EMU Notes in Mineralogy 6. 281-343.

Petтijohn, F.J. 1952. Sedimentary Rocks. $2^{\text {nd }}$ edition. New York, Harper.

Rogers, C.D.F. and Smalley, I.J. 1993. The shape of loess particles. Naturwissenschaften 80. 461-462.

SChäFer, A. and Teyssen, T. 1987. Size, shape and orientation of grains in sands and sandstones-image analysis applied to rock thin-sections. Sedimentary Geology 52. 251-271.

SEndula, E. 2015. Ipari CO tárolásra alkalmas hazai üledékes kózzetek petrográfiai vizsgálata és a rendszerekben várható geokémiai változások modellezése (Petrographical analyses of Pannonian sedimentary rocks, which are suitable to industrial $\mathrm{CO}_{2}$ storage and geochemical modelling of the system). MSc Thesis. Budapest, ELTE Kőzettan-Geokémia Tanszék.

Sochan, A., Zieliński, P. and Bieganowski, A. 2015. Selection of shape parameters that differentiate sand grains, based on the automatic analysis of twodimensional images. Sedimentary Geology 327. 14-20.

Szamosfalvi, Á., Falus, Gy. and Juhász, Gy. 2011. The potential options of storing $\mathrm{CO}_{2}$ in saline reservoirs in Hungary. Magyar Geofizika 52. (2): 95-105. (In Hungarian with English abstract.)
Varga, Gy. and Roettig, C.-B. 2018. Identification of Saharan dust particles in Pleistocene dune sandpaleosol sequences of Fuerteventura (Canary Islands). Hungarian Geographical Bulletin 67. (2) 121-141.

Varga, Gy., Gresina, F., Újvári, G., Kovács, J. and Szalai, Z. 2019. On the reliability and comparability of laser diffraction grain size measurements of paleosols in loess records. Sedimentary Geology 389. 42-53.

Varga, Gy., Kovács, J., Szalai, Z., Cserháti, Cs. and ÚJVÁRI, G. 2018. Granulometric characterization of paleosols in loess series by automated static image analysis. Sedimentary Geology 370. 1-14.

Wentworth, C.K. 1922. A scale of grade and class terms for clastic sediments. The Journal of Geology 30. 377-392.

XIA, W. 2017. Role of particle shape in the floatability of mineral particle: An overview of recent advances. Powder Technology 317. 104-116.

ZACHÁRY, D. 2019. Applications of stable carbon isotopes in soil science with special attention to natural ${ }^{13} \mathrm{C}$ abundance approach. Hungarian Geographical Bulletin 68. (1): 3-20.

Zacháry, D., Filep, T., Jakab, G., Varga, Gy., Ringer, M. and SzalaI, Z. 2018. Kinetic parameters of soil organic matter decomposition in soils under forest in Hungary. Geoderma Regional 14. e00187. 
